\title{
TESTING THE “DICARB PROBLEM”: A CASE STUDY FROM NORTH ALASKA
}

\author{
Joshua D Reuther \\ Northern Land Use Research, Inc., 600 University Ave., Suite 6, Fairbanks, Alaska 99708, USA. \\ Corresponding author. Email: josh_reuther@yahoo.com. \\ S Craig Gerlach \\ Department of Chemistry and Biochemistry, Department of Anthropology, P.O. Box 757720, University of Alaska, \\ Fairbanks, Alaska 99775-7720, USA.
}

\begin{abstract}
An assumption exists in North Alaskan archaeological literature that radiometric assays produced by the nowdefunct Dicarb Radioisotope Co. (Dicarb) are "too young" or more recent when compared to those produced by other laboratories. This assumption is statistically tested by comparing radiocarbon assays produced by Dicarb to those produced by Beta Analytic, Inc.; Geochron Laboratories; and the NSF-Arizona AMS Facility. The primary data set consists of radiometric and accelerator mass spectrometry (AMS) assays produced from materials excavated at the Croxton site, Locality J, Tukuto Lake, northern Alaska. Statistical analyses demonstrate that ${ }^{14} \mathrm{C}$ assays produced by Dicarb tend to be "younger" than assays produced by other laboratories on crosscheck samples, with differences ranging between 350 and $1440 \mathrm{yr}$.
\end{abstract}

\section{INTRODUCTION}

The purpose of this research is to examine potential differences between radiocarbon dates produced by the inactive Dicarb Radioisotope Co. (Dicarb/DIC) when compared to those produced by Beta Analytic, Inc. (Beta); Geochron Laboratories (Geochron/GX); and the NSF-University of Arizona AMS Facility (NSF-Arizona AMS/AA). There exists an assumption within the North Alaskan archaeological community that radiometric assays produced by Dicarb are "too young" when compared to those produced by other laboratories from the same archaeological contexts (Gal 1982a; Gerlach 1989; Gerlach and Hall 1988; Gerlach and Mason 1992; Minc and Smith 1989; Reanier 1992). This assumption is informally known as the "Dicarb problem" in the North Alaskan archaeological community.

As a case study, standard radiometric (liquid scintillation) and accelerator mass spectrometry (AMS) assays $(n=14)$ produced from materials excavated at the Croxton site, Locality $\mathbf{J}$ (Croxton, Loc. J), Tukuto Lake, northern Alaska, are used as the primary data set within this research (Figure 1). The discussion surrounding the chronometric position of the Ipiutak occupation at Croxton, Loc. J, exemplifies the debate surrounding the Dicarb problem (Gerlach 1989; Gerlach and Hall 1988; Gerlach and Mason 1992; Mason and Gerlach 1995; Mason 1998, 2000; Minc and Smith 1989; Reanier 1992). Over 700 Dicarb ${ }^{14} \mathrm{C}$ dates from archaeological sites and paleontological specimens throughout North America are noted in the Canadian Archaeological Radiocarbon Database (CARD; www.canadianarchaeology.ca).

\section{DESCRIPTIVE BACKGROUND}

\section{Research at the Croxton Site, Locality J}

Croxton, Loc. J, was discovered in 1980 by Bureau of Land Management (BLM) archaeologists Michael L Kunz, Peter M Bowers, and Robert Gal. Excavations were conducted from 1981-1983 under the direction of S Craig Gerlach (Gerlach 1989) with support from the BLM, United States Geological Survey, and the National Science Foundation. During a 2-week period in 2000, a small crew from the University of Alaska, Fairbanks returned for 2 weeks in order to answer specific unresolved questions relating to the chronometric and stratigraphic position of 2 known occupations at the site. Charcoal and organic samples were collected for ${ }^{14} \mathrm{C}$ dating. A total of $3008 \mathrm{ft}^{2}$ (approx. $5 \%$ ) of the $60,000 \mathrm{ft}^{2}$ of an artificial grid has been excavated to date. 


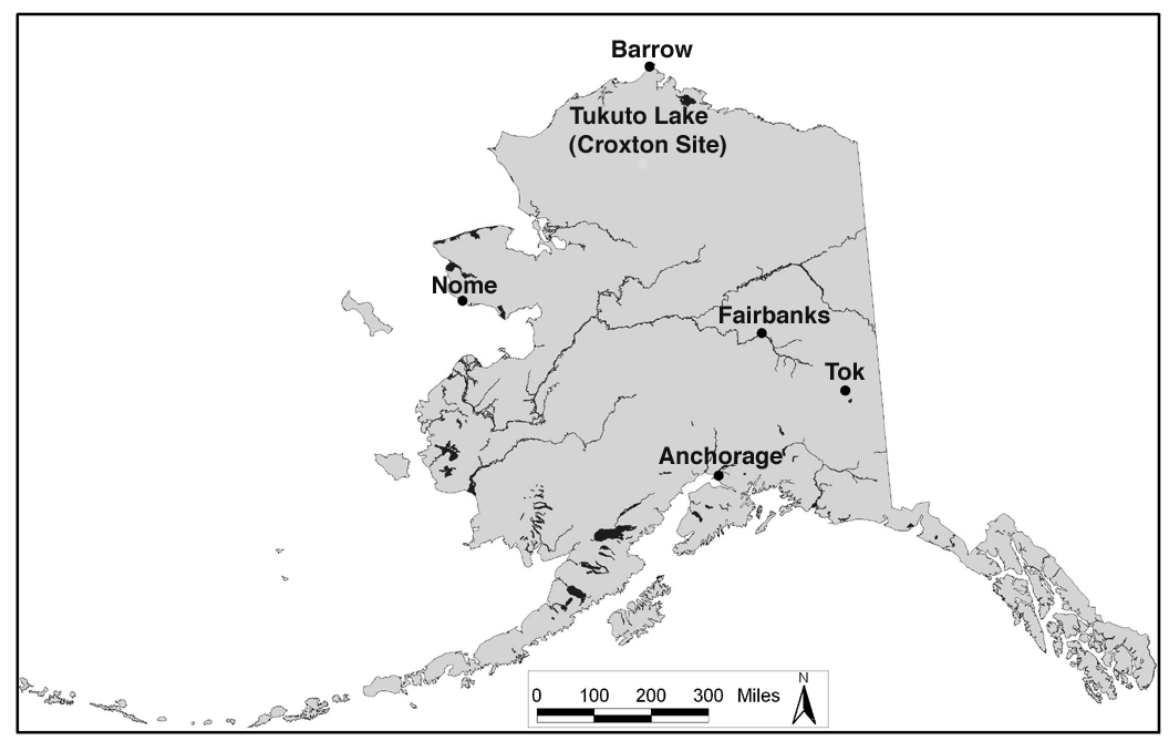

Figure 1 Location of Tukuto Lake and the Croxton site in Alaska

The excavations at Croxton, Loc. J, produced an immense quantity of artifactual and faunal material, including a wide variety of lithic implements and exceptionally well-preserved organic remains. Typological comparison of artifacts and ${ }^{14} \mathrm{C}$ dating revealed the presence of 2 components: an Arctic Small Tool tradition (ASTt) and an Ipiutak component (Gerlach and Hall 1988; Gerlach 1989). Lithic artifacts from the older component display stylistic similarities to those of the ASTt, as defined by Irving (1962, 1964), and the Denbigh Flint culture (Giddings 1951, 1964; Gerlach 1989). The Denbigh Flint culture (Denbigh) is encompassed within the ASTt (Irving 1962, 1964), along with other eastern arctic archaeological cultures including Independence and Pre-Dorset. ASTt sites are situated along the coastline from the Alaska Peninsula to Barrow, east through the Canadian arctic and into Greenland (Dumond 1987). ASTt sites are also situated in the interior regions of North Slope and Brooks Range, Alaska (Anderson 1988; Irving 1964; Gerlach 1989; Kunz 1977). Diagnostic hallmarks of the ASTt lithic technology are finely flaked, relatively small sideblades and endblades made for insetting into composite arrowheads, spearheads, knives, and harpoon heads composed of organic materials such as antler, bone, or ivory (Anderson 1980; Dumond 1987). Other lithic implements that are unique to the ASTt include microblades and microcores, flake knives, and burins removed from bifaces, known as "mitten burins." The subsistence system of the ASTt may have placed an emphasis on interior fauna, in particular caribou, and marine resources such as seals (Anderson 1988; Dumond 1980, 1987). The terms Denbigh and the ASTt are sometimes used synonymously, and it has been suggested that they represent the earliest remains ancestral to modern Eskimo populations (Anderson 1980; Dumond 1980).

The artifactual material from the more recent component displays stylistic similarities to organic artifacts and lithic types from the archaeologically defined Ipiutak culture at Point Hope, located along the coast of the Lisburne Peninsula, and the inland Bateman site, located in the Itkillik Valley of the Brooks Range (Larsen and Rainey 1948; Gerlach and Hall 1988; Gerlach 1989; Reanier 1992). The Ipiutak culture is well known for its intricate carvings and decorative incising of bone, antler, and ivory. Large composite masks, open-work carvings including swivels and chain links, and animal and human figurines that depict their skeletal structure are the best known organic arti- 
fact types from Ipiutak assemblages such as Point Hope (Larsen and Rainey 1948). Both anthropomorphic and zoomorphic themes are represented in carvings and composite masks. The lithic technology of Ipiutak is similar to that of the ASTt; however, several artifact types unique to the ASTt, such as microblades and microblade cores and "mitten" burins, are lacking in Ipiutak assemblages (Dumond 1987). Several researchers have suggested a reliance on terrestrial fauna (especially caribou) in the Ipiutak subsistence system (Dumond 1980; Larsen and Rainey 1948).

In 1982, $24{ }^{14} \mathrm{C}$ samples from Croxton, Loc. J, were dated by 2 different laboratories: Dicarb and Geochron (Gal 1982b; Gerlach 1989). Nineteen radiometric assays were provided by Dicarb and another five by Geochron. A time range of $1260 \pm 65$ (DIC-2020) to $550 \pm 125$ BP (DIC-2461) was proposed for the Ipiutak component on the basis of 12 of the assays produced by Dicarb (Gerlach 1989). A time range of $4420 \pm 410 / 430$ (DIC-2204) to $2210 \pm 155$ BP (DIC-2465) was proposed for the ASTt component on the basis of 3 assays provided by Dicarb (Gerlach 1989). One assay produced by Dicarb of $290 \pm 100$ BP (DIC-2464) is presented in Appendix II by Gerlach (1989:465-9; also see Gal 1982b:164), but this date is neither discussed in the text nor attributed to either Loc. $\mathrm{J}$ component. Three additional samples submitted to Dicarb in 1982 were deemed "too small to produce a reliable date" (Dicarb Radioisotope Co., laboratory results sheets, accession UA81-119 and UA82-080 files, Department of Archaeology, University of Alaska Museum, Fairbanks).

A time range of $1350 \pm 140$ (GX-8633) to $1135 \pm 135 \mathrm{BP}$ (GX-8634) was proposed for the Ipiutak component on the basis of 3 assays provided by Geochron. One assay for the ASTt component of $3680 \pm 205 \mathrm{BP}$ (GX-8637) was provided by Geochron. One Geochron date of $1670 \pm 160 \mathrm{BP}$ (GX8636) was recovered from a stratigraphically "transitional" layer between the ASTt and Ipiutak components present in some areas of Loc. J. The date was ultimately attributed to the ASTt component on the basis of artifactual material and the presence of a transitional stratigraphic break (Gerlach 1989:151).

In summary, the 1982 dates place the time range for the Ipiutak component at the Croxton, Loc. J, between 1350-550 BP; this is based on the complete suite of dates produced by Dicarb and Geochron (Gerlach and Hall 1988:118-9; Gerlach 1989:152). The general time frame established by the $1982{ }^{14} \mathrm{C}$ dates for the ASTt component at Croxton, Loc. J, is 4420-3350 BP and 2210-1670 BP (Gerlach and Hall 1988:118-9; Gerlach 1989:151-4).

\section{The "Dicarb Problem" and the Late Inland Interior Ipiutak Debate}

The $1982{ }^{14} \mathrm{C}$ dating of the 2 Loc. J components challenged previously held notions of the chronological position and temporal relationships of the ASTt and Ipiutak in North Alaskan prehistory (Gerlach 1989; Gerlach and Hall 1988; Gerlach and Mason 1992; Mason and Gerlach 1995). ASTt (Denbigh) has a similar lithic technology to those later archaeological entities Choris, Norton, and Ipiutak. The separation of these archaeological entities is primarily based on the presence or absence of artifact types, organic artifact styles, and ${ }^{14} \mathrm{C}$ dates. Two main cultural-historical schemes have been constructed that focus on these time periods and archaeological entities and the relationships between and among them (Anderson 1968; Dumond 1982, 2000).

Dumond $(1982,2000)$ strictly adheres to the original definition of the ASTt (Irving 1962, 1964), separating it from the archaeological entities Choris, Norton, and Ipiutak. Dumond $(1982,2000)$ combines Choris, Norton, and Ipiutak into a "Norton tradition." In contrast, Anderson $(1968,1988)$ combines the ASTt, Choris, Norton, and Ipiutak under the definition of the Arctic Small Tool tradition. 
Whether one of these cultural-historical schemes is favored over the other, the chronometric position for the ASTt and Ipiutak follows traditional notions within the archaeological literature of North Alaskan prehistory, especially Ipiutak (Anderson 1968; Dumond 1982, 2000; Irving 1964; Mason 2000; Minc and Smith 1989; Reanier 1992). Dates cited by many arctic archaeologists for the ASTt typically range between 4700-3600 BP (Anderson 1978, 1984; Dumond 1980, 1987; Harritt 1998). However, an interior ASTt assemblage from the Mosquito Lake site located in the foothills of the central Brooks Range dates to as recently as 2500 BP (Kunz 1977). More conventional and widely accepted notions of the chronometric position of Ipiutak assume a date range of 1650-1200 BP based on ${ }^{14} \mathrm{C}$ assays (Anderson 1984; Dumond 1987, 2000; Mason 2000; Minc and Smith 1989; Reanier 1992).

While the Loc. J conventional ${ }^{14} \mathrm{C}$ dates provided by Geochron support more traditional ideas about the chronological and temporal position of both the ASTt and Ipiutak components within arctic prehistory, the Dicarb dates do not. The Dicarb radiometric assays produced a chronology that made both components appear to be considerably more recent than many archaeologists appeared willing to accept (Gal 1982a; Minc and Smith 1989; Reanier 1992).

With the Croxton site chronology as the basis for the argument, Gerlach (1989), Gerlach and Hall (1988), and Gerlach and Mason (1992) argued for a late inland-oriented Ipiutak occupation that "continued to thrive in the Brooks Range long after they disappeared elsewhere" (Gerlach 1989: 169). After calibration of the 1982 Croxton, Loc. J, ${ }^{14} \mathrm{C}$ dates and calibration of dates from a wide variety of other presumably related sites, Gerlach and Mason (1992:63) further argued that "there is indeed a northern inland Ipiutak occupation that is significantly later than that on the coast."

After the 1982 Croxton ${ }^{14} \mathrm{C}$ dates were published (Gal 1982b; Gerlach 1989: Appendix II) and the implications of the dating were used as the basis for the development of a modified cultural-historical model for North Alaskan prehistory (Gerlach 1989; Gerlach and Hall 1988), several researchers began to question the discrepancies between dates produced by Geochron and Dicarb (Minc and Smith 1989; Reanier 1992). For example, one large charcoal sample collected in 1982 was intentionally split in half by Gerlach for control, with one fraction sent to Dicarb and the other sent to Geochron for assay (Gerlach 1989:152). Assays produced by the 2 labs provided considerably different results: $570 \pm 45$ BP (DIC-2459) and $1135 \pm 135$ BP (GX-8634), with a 565-yr difference between 2 fractions of the same charcoal sample.

In questioning the Croxton, Loc. J, chronology, specifically the Ipiutak component, Minc and Smith (1989:39) observed that "[o]ne laboratory's dates [Geochron] place the [Ipiutak] component between [uncalibrated] AD 600 and 800, the other's [Dicarb] between [uncalibrated] AD 1000 and 1400. The former set conforms to other estimates for the antiquity of the Ipiutak complex. However, until the discrepancy in laboratory dates can be resolved, the true age of the Croxton component remains uncertain." Interestingly, the chronometric position of the Croxton, Loc. J, ASTt component based on the Dicarb ${ }^{14} \mathrm{C}$ assays was not called into question, even though the dates did not conform to traditionally accepted historical-frameworks established for North Alaskan prehistory. Several other researchers have also noted and questioned the discrepancies between assays analyzed by Dicarb and another laboratory wherever samples were split and/or collected within close association to one another (Gal 1982a; Kunz and Reanier 1995). The controversy rests on the fact that many North Alaskan archaeologists, implicitly or explicitly, consider a majority or all of the Dicarb dates to be consistently "too young," "errant," and/or "unreliable" (Mason 2000; Minc and Smith 1989; Reanier 1992). 


\section{METHODS}

The main goal of this study is to statistically compare ${ }^{14} \mathrm{C}$ assays produced by Dicarb to those produced by other laboratories on the same sample or materials from an associated context. If differences do occur between the comparisons, we explore if a pattern among the discrepancies exists, i.e. consistently older versus younger. In order to assess the assumption that ${ }^{14} \mathrm{C}$ dates produced by Dicarb are aberrant or too young when compared to those produced from other laboratories, split samples and crosschecks of samples that were used to produce assays by Dicarb were sent to Beta, Geochron, and NSF-Arizona AMS. Archived samples were assessed for their contextual integrity and the potential for mixture of younger and older materials due to taphonomic processes, such as cryoturbation. ${ }^{1}$

Organic samples originally dated by Dicarb and archived at the University of Alaska Museum of the North (UAM) were split and sent to Beta and NSF-Arizona AMS for AMS dating in 1999-2000. ${ }^{2}$ In addition, several organic samples within close association to original samples dated by Dicarb, where split samples could not be recovered, were sent into Beta and NSF-Arizona AMS and used as comparative crosschecks. The original split sample assayed by Dicarb and Geochron in 1982 is also used in this study. The term crosscheck will be used to refer to both split and crosscheck samples throughout the rest of the text.

\section{RESULTS}

To assess the potential for groupings by laboratories of contemporaneous or nearly coeval assays, pair-wise tests of contemporaneity were conducted for the ASTt and Ipiutak ${ }^{14} \mathrm{C}$ assays following Spaulding (1958), Thomas (1986:249-51), and Shott (1992:212-3). If the assumption that Dicarb assays are more recent when compared to those produced by other laboratories, Dicarb assays should cluster in a contemporaneous or near-contemporaneous group separate from the other laboratories. Table 1 shows pair-wise tests of contemporaneity for the Ipiutak component ${ }^{14} \mathrm{C}$ dates. The values for the 4 Dicarb dates are significantly different when compared to dates from the other laboratories, with the exception of DIC-2206 versus GX-8634. These results indicate a lack of contemporaneity between the Dicarb dates and those produced by other laboratories. Pair-wise testing among the Dicarb dates was statistically insignificant, indicating contemporaneity within the laboratory's assays. Pair-wise test values among Beta, Geochron, and NSF-Arizona AMS dates are insignificant and indicate contemporaneity among the 3 laboratories' results.

Table 2 shows the results for pair-wise tests of contemporaneity for the ASTt component dates. The values for the 3 Beta assays are statistically insignificant when compared to each other and suggest contemporaneity. The values for 2 Dicarb dates are statistically significant when compared to each other and to the Beta dates, again indicating a lack of contemporaneity. The results of the pair-wise testing for both components' dates show that Dicarb produced significantly different assay values when compared to the other laboratories from the same component.

Crosscheck pairs are listed in Table 3. The $t$ statistic was employed, following Case II of Ward and Wilson (1978) using the Calib program (revision 5.0) of Stuiver and Reimer (1993) and Stuiver et al. (1998), to explore differences among individual crosscheck pairs. The results of the test statistic

\footnotetext{
${ }^{1}$ One sample dated by Dicarb (DIC-2464, $290 \pm 100$ ) and Beta (Beta-138715, $3620 \pm 40$ ) was recovered from an area of Croxton, Loc. J, that has extensive cryoturbation within the substrate and the potential mixing of older and younger materials. The contextual integrity of the sample is questionable and disregarded from this study.

${ }^{2}$ Beta-129945, -129946, and -130192 were originally reported in Carrigan (1999) and Oswald et al. (2001).
} 
Table 1 Pair-wise test of contemporaneity of Ipiutak ${ }^{14} \mathrm{C}$ results $\left(n=9, t_{0.05}=1.96, \mathrm{df}=\infty\right)$.

\begin{tabular}{llllllllll}
\hline & & Beta- & Beta- & Beta- & DIC- & DIC- & DIC- & DIC- & GX- \\
Lab nr & AA51441 & 129945 & 129946 & 130192 & 2205 & 2206 & 2459 & 2461 & 8634 \\
\hline AA51441 & n/a & & & & & & & & \\
Beta-129945 & 1.41 & n/a & & & & & & & \\
Beta-129946 & 0.02 & 1.93 & n/a & & & & & & \\
Beta-130192 & 0.28 & 1.72 & 0.0 & n/a & & & & & \\
DIC-2205 & 3.28 & 3.83 & 3.2 & 3.2 & n/a & & & & \\
DIC-2206 & 2.44 & 2.88 & 2.37 & 2.37 & 0.15 & n/a & & & \\
DIC-2459 & 10.90 & 12.83 & 11.00 & 9.81 & 0.57 & 0.64 & n/a & & \\
DIC-2461 & 5.19 & 6.03 & 5.19 & 5.19 & 0.57 & 0.64 & 0.15 & n/a & \\
GX-8634 & 0.80 & 1.45 & 0.68 & 0.66 & 2.14 & 1.67 & 3.98 & 3.18 & n/a \\
\hline
\end{tabular}

Table 2 Pair-wise test of contemporaneity of ASTt ${ }^{14} \mathrm{C}$ results $\left(n=5, t_{0.05}=1.96, \mathrm{df}=\infty\right)$.

\begin{tabular}{llllll}
\hline Lab nr & Beta-134995 & Beta-134996 & Beta-136257 & DIC-2465 & DIC-2469 \\
\hline Beta-134995 & n/a & & & & \\
Beta-134996 & 1.05 & n/a & & & \\
Beta-136257 & 1.72 & 0.78 & n/a & & \\
DIC-2465 & 9.69 & 9.31 & 8.83 & n/a & \\
DIC-2469 & 5.69 & 4.86 & 3.85 & 6.87 & n/a \\
\hline
\end{tabular}

Table 3 Results of $t$ tests conducted on assays produced by Dicarb when compared to those produced by other laboratories on crosscheck samples $\left(n=9 ; \mathrm{X}_{0.05}=3.84 ; \mathrm{df}=1\right)$. Significant values are given in bold-faced font.

\begin{tabular}{|c|c|c|c|c|c|c|c|}
\hline Lab nr & $\begin{array}{l}\text { Conventional } \\
\text { age }(\mathrm{BP})\end{array}$ & Other lab nr & $\begin{array}{l}\text { Conventional } \\
\text { age }(\mathrm{BP})\end{array}$ & $\begin{array}{l}\text { Difference } \\
\text { (D) }\end{array}$ & $\begin{array}{l}\text { Standard } \\
\text { error of the } \\
\text { Difference }\end{array}$ & $t$ test & $P$ value \\
\hline DIC-2461 & $550 \pm 125$ & Beta-129945 & $1340 \pm 40$ & 790 & 131 & 36.23 & $<0.001$ \\
\hline DIC-2459 & $570 \pm 45$ & Beta-130192 & $1230 \pm 50$ & 660 & 67 & 96.27 & $<0.001$ \\
\hline DIC-2459 & $570 \pm 45$ & GX-8634 & $1135 \pm 135$ & 565 & 142 & 15.76 & $<0.001$ \\
\hline DIC-2459 & $570 \pm 45$ & AA51441 & $1250 \pm 50$ & 680 & 67 & 102.19 & $<0.001$ \\
\hline DIC-2205 & $670 \pm 170$ & Beta-129945 & $1340 \pm 40$ & 670 & 175 & 14.72 & $<0.001$ \\
\hline DIC-2206 & $710 \pm 215$ & Beta-129946 & $1230 \pm 40$ & 520 & 219 & 5.65 & $0.005>P<0.025$ \\
\hline DIC-2465 & $2210 \pm 155$ & Beta- 136257 & $3650 \pm 50$ & 1440 & 163 & 78.18 & $<0.001$ \\
\hline DIC-2469 & $3350 \pm 60$ & Beta-134995 & $3760 \pm 40$ & 410 & 72 & 32.33 & $<0.001$ \\
\hline DIC-2469 & $3350 \pm 60$ & Beta-134996 & $3700 \pm 40$ & 350 & 72 & 23.56 & $<0.001$ \\
\hline
\end{tabular}

further demonstrate significant differences among the ${ }^{14} \mathrm{C}$ assays produced by Dicarb when compared to those produced by Beta, Geochron, and NSF-Arizona AMS on crosscheck samples (Table 3). As all of the $t$ tests resulted in significant values, the differences between Dicarb dates and assays produced by other laboratories are not likely due to random chance alone.

Correlation coefficients were conducted to assess the direction (positive or negative) of the relationship between the crosscheck variables. A Pearson's correlation coefficient $(r)$ shows a strong positive correlation $(r=0.966)$ between the assays produced by Dicarb when compared to those produced by Beta, Geochron, and NSF-Arizona AMS on crosscheck samples. The correlation 
coefficient results (significant at a 0.01 level of significance) demonstrate that as Dicarb assay estimates increase in age, the comparison assays also increase in age. Two non-parametric correlation coefficients, Kendall's tau- $b\left(\tau_{\mathrm{b}}=0.628\right)$ and Spearman's $r h o\left(r_{\mathrm{s}}=0.742\right)$, display a positive relationship between Dicarb and comparative assays, only slightly weaker than the results produced by the Pearson's $r$. The results of the non-parametric correlation coefficients are significant at a 0.05 level of significance. As the correlation coefficients display a strong positive relationship among Dicarb and comparative assays, the $t$ test results support the verity of this relationship.

\section{DISCUSSION AND CONCLUSIONS}

${ }^{14} \mathrm{C}$ assays provided by Dicarb were compared to those produced by Beta, Geochron, and NSF-Arizona AMS in order to assess potential differences among them. The results of this research have shown that the "Dicarb problem" is a bona fide phenomenon, and Dicarb dates are significantly more recent than those produced by the other laboratories on crosscheck samples. The question of why these assays are consistently more recent than those of other laboratories remains unresolved, though some of the possibilities may include a systematic contamination in the laboratory's procedures, mechanical malfunction, or even improper set up of the counting equipment. The use of Dicarb assays in chronology building should be viewed with skepticism.

\section{ACKNOWLEDGMENTS}

We would like to thank several people that have contributed to this research: Carol GelvinReymiller, Catherine Williams, Angela Linn, Ben A Potter, and Larry Duffy for editing an earlier draft of this paper; Pete Bowers, Maribeth Murray, Joel Irish, Richard Reanier, and Owen Mason for the extensive discussions on the subject; Michael Kunz and Robin Mills of the BLM, the Geist Fund, University of Alaska Museum of the North, and the Office of Arctic Research, University of Alaska, Fairbanks, for financial support.

\section{REFERENCES}

Anderson DD. 1968. A Stone Age campsite at the gateway to America. Scientific American 218(6):24-33.

Anderson DD. 1978. Western Arctic and Subarctic. In: Taylor RE, Meighan CW, editors. Chronologies in New World Archaeology. New York: Academic Press. p 29-50.

Anderson DD. 1980. Continuity and change in the prehistoric record from North Alaska. In: Kotani Y, Workman WB. Alaska Native Culture and History. Senri Ethnological Studies 4. Osaka: National Museum of Ethnology. p 233-51.

Anderson DD. 1984. Prehistory of North Alaska. In: Damas D, editor. Arctic. Handbook of North American Indians, Vol. 5, Sturvtevant WC, general editor. Washington D.C.: Smithsonian Institution. p 80-93.

Anderson DD. 1988. Onion Portage: the archaeology of a stratified site from the Kobuk River, northwest Alaska. Anthropological Papers of the University of Alaska 22(1-2):1-163.

Carrigan KD. 1999. The Croxton site: analysis of lithic tools and debitage [unpublished Master's research project on file]. Fairbanks: Department of Anthropology, University of Alaska, Fairbanks.

Dumond DE. 1980. A chronology of native Alaskan subsistence systems. In: Kotani Y, Workman WB. Alaska Native Culture and History. Senri Ethnological Studies 4. Osaka: National Museum of Ethnology. p 23-47.

Dumond DE. 1982. Trends and traditions in Alaskan prehistory: the place of Norton culture. Arctic Anthropology 19(2):39-51.

Dumond DE. 1987. The Eskimos and Aleuts. London: Thames and Hudson. 180 p.

Dumond DE. 2000. The Norton tradition. Arctic Anthropology 37(2):1-22.

Gal R. 1982a. Archaeological sites in the vicinity of the South Meade test well. Anthropological Papers of the University of Alaska 20(1-2):51-9.

Gal R. 1982b. Appendix I. An annotated and indexed roster of archaeological radiocarbon dates from Alaska, north of $68^{\circ}$ latitude. Anthropological Papers of the University of Alaska 20(1-2):159-80.

Gerlach SC. 1989. Models of caribou exploitation, butchery and processing at the Croxton site, Tukuto Lake, Alaska [PhD dissertation]. Providence: Department of Anthropology, Brown University. University Microfilms, Ann Arbor, Michigan, USA.

Gerlach SC, Hall ES Jr. 1988. The later prehistory of 
northern Alaska: the view from Tukuto Lake. In: Shaw RD, Harrit RK, Dumond DE, editors. The Late Prehistoric Development of Alaska's Native People. Aurora Monograph Series No. 4. Anchorage: Alaska Anthropological Association. p 107-35.

Gerlach SC, Mason OK. 1992. Calibrated radiocarbon dates and cultural interaction in the western Arctic. Arctic Anthropology 29(1):54-81.

Giddings JL. 1951. The Denbigh flint complex. American Antiquity 16(3):193-203.

Giddings JL. 1964. The Archaeology of Cape Denbigh. Providence: Brown University Press. 331p.

Harritt RK. 1998. Paleo-Eskimo beginnings in North America: a new discovery at Kuzitrin Lake, Alaska. Etudes/Inuit/Studies 22(1):61-81.

Irving WN. 1962. A provisional comparison of some Alaskan and Asian stone industries. In: Campbell JM, editor. Prehistoric Cultural Relations Between the Arctic and Temperate Zones of North America. Montreal: Arctic Institute of North America, Technical Paper No. 11. p 55-68.

Irving WN. 1964. Punyik Point and the Arctic small tool tradition [PhD dissertation]. Madison: Department of Anthropology, University of Wisconsin. University Microfilms, Ann Arbor.

Kunz ML. 1977. Mosquito Lake site (PSM-049). In: Cook JP, editor. Pipeline Archaeology. Fairbanks: Institute of Arctic Biology, University of Alaska, Fairbanks. p 747-982.

Kunz ML, Reanier RE. 1995. The Mesa site: a paleoindian hunting lookout in arctic Alaska. Arctic Anthropology 32(1):5-30.

Larsen H. 2001. Deering - A Men's House from Seward Peninsula, Alaska. Publications of the National Museum, Ethnological Series, Vol. 19. Copenhagen: Department of Ethnography and SILA-the Greenland Research Centre, National Museum of Denmark.

Larsen H, Rainey F. 1948. Ipiutak and the Arctic whale hunting culture. Anthropological Papers of the American Museum of Natural History 42:1-276.

Mason OK. 1998. The contest between Ipiutak, Old Bering Sea, and Birnirk polities and the origin of whaling during the first millennium $\mathrm{AD}$ along the Bering Strait. Journal of Anthropological Archaeology 17: 240-325.

Mason OK. 2000. Archaeological Rorschach in delineating Ipiutak, Punuk and Birnirk in NW Alaska: mas- ters, slaves or partners in trade? In: Applet M, Berglund J, Gullov HC, editors. Identities and Cultural Contacts in the Arctic: Proceedings from a Conference at the Danish National Museum, Copenhagen. Copenhagen: The Danish National Museum and Danish Polar Centre. p 229-51.

Mason OK, Gerlach SC. 1995. Chukchi hotspots, paleopolynyas, and caribou crashes: climatic and ecological dimensions of North Alaska prehistory. Arctic Anthropology 32(1):101-30.

Minc L, Smith KP. 1989. The spirit of survival: cultural responses to resource variability in North Alaska. In: Halstead P, O'Shea J, editors. Bad Year Economics: Cultural Responses to Risk and Uncertainty. Cambridge: Cambridge University Press. p 8-39.

Oswald WW, Brubaker LB, Anderson PM, Gerlach SC. 2001. Late Holocene environmental and cultural changes at Tukuto Lake, northwestern Alaska. In: Gerlach SC, Murray MS, editors. People and Wildlife in Northern North America: Essays in Honor of $R$ Dale Guthrie. BAR International Series 944. Oxford: Archaeopress.

Reanier RE. 1992. Refinements to K-means clustering: spatial analysis of the Bateman site, arctic Alaska [PhD dissertation]. Seattle: Department of Anthropology, University of Washington.

Shott MJ. 1992. Radiocarbon dating as a probabilistic technique: the Childer's site and Late Woodland occupation in the Ohio Valley. American Antiquity 57(2): 202-30.

Spaulding AC. 1958. The significance of differences between radiocarbon dates. American Antiquity 23(3): 309-11.

Stuiver M, Reimer PJ. 1993. Extended ${ }^{14} \mathrm{C}$ database and revised CALIB radiocarbon calibration program. Radiocarbon 35(1):215-30.

Stuiver M, Reimer PJ, Bard E, Beck JW, Burr GS, Hughen KA, Kromer B, McCormac FG, van der Plicht J, Spurk M. 1998. IntCal98 radiocarbon age calibration, 24,000-0 cal BP. Radiocarbon 40(3):1041-83.

Thomas DT. 1986. Refiguring Anthropology: First Principles of Probability and Statistics. Prospect Heights, Illinois: Waveland Press. 532 p.

Ward GK, Wilson SR. 1978. Procedures for comparing and combining radiocarbon age determinations: a critique. Archaeometry 20(1):19-31. 